\title{
The quality of life of patients with cerebral palsy versus the general population
}

\author{
Marta Lewicka', Andrzej Kurylak² \\ 'Department of Social Nursing, Faculty of Health Sciences, Ludwik Rydygier Collegium Medicum in Bydgoszcz, \\ Nicolaus Copernicus University in Torun, Poland \\ ${ }^{2}$ Department of Paediatric Nursing, Faculty of Health Sciences, Ludwik Rydygier Collegium Medicum in Bydgoszcz, \\ Nicolaus Copernicus University in Torun, Poland
}

\section{ABSTRACT}

Introduction: Cerebral palsy $(\mathrm{CP})$ is the most common cause of motor disability among children. This disease, as a compound syndrome, affects the biological, psychological, and social functioning of a patient and has different degrees. Feedback from studies on the quality of life (QoL) of children with CP make it possible to improve the relationship between a child suffering from $\mathrm{CP}$ and the surrounding external environment. Obtained information about the patient's frame of mind and the limitations caused by CP allow us to perceive the problems that children suffer and take actions aimed at solving them. Improving the QoL of children with CP becomes one of the main goals of therapeutic interaction - in parallel with the alleviation of disease symptoms.

Aim of the study: To assess the QoL of patients with CP as compared to the general population.

Material and methods: The study was conducted among 128 patients with CP. The reference group consisted of 130 healthy subjects. The study was of prospective nature, conducted using a diagnostic survey based on the Pediatric Quality of Life Inventory (PedsQL) 4.0 Generic Core.

Results: Healthy children are characterised by better overall QoL. They also achieved significantly higher scores in individual subscales (physical, emotional, social, school, and psycho-social functioning) excluding emotional functioning.

Conclusions: There is a need to implement comprehensive therapy for children with CP that enables self-care, or assistance in everyday self-care and school activities. It also seems important to adapt the home and school environment in accordance with the needs of patients suffering from CP.

\section{KEY WORDS:}

children, quality of life, cerebral palsy.

\section{INTRODUCTION}

Cerebral palsy $(\mathrm{CP})$ is the most common cause of motor disability among children [1-3]. Motor and postural disorders as well as sensory, cognitive, perceptual, and communication disorders limit the activity of patients and may lead to a decrease in the quality of their lives [4-9]. The interest in the subject of quality of life (QoL) in patients with chronic diseases, including children, has been increasing in recent years. The QoL is a broad concept that covers various aspects of human activity. Assessment of the QoL is a very complex issue which is difficult to

\section{ADDRESS FOR CORRESPONDENCE:}

Marta Lewicka, Department of Social Nursing, Faculty of Health Sciences, Ludwik Rydygier Collegium

Medicum in Bydgoszcz, Nicolaus Copernicus University in Torun, 1 Łukasiewicza St., 85-001 Bydgoszcz,

Poland, ORCID: 0000-0002-6190-1895, e-mail: marta_grabinska@hotmail.com 
interpret; however, it is a valuable source of information about a patient, and at the same time can be one of the main indicators of the effectiveness of modern therapy. Information obtained about the patient's physical and mental state and the limitations caused by CP allow us to perceive problems experienced by children and to take actions aimed at solving them. The QoL improvement in children with $\mathrm{CP}$ is becoming one of the main goals of therapeutic interventions, in parallel with the relief of disease symptoms. The aim of the paper is to present the QoL of patients with $\mathrm{CP}$ as compared to the general population.

\section{MATERIAL AND METHODS}

The study was carried out among 128 patients (61 boys and 67 girls) of the Josef Brudziński Provincial Children's Hospital in Bydgoszcz, who were 2 to 18 years old. The study was of prospective nature and was carried out using the diagnostic survey method. The questionnaires used in the study were not filled out by patients with CP themselves, but by their parents. The self-assessment of patients was abandoned due to mental disability and communication difficulties with the majority of them.

A total of 130 children ( 64 girls and 66 boys) who did not suffer from chronic diseases, aged 2 to 18 , were qualified to the control group. The study on healthy children was carried out among pupils of the primary school, middle school, and kindergarten in Bydgoszcz and Więcbork.

Due to the fact that the questionnaires in the study group were filled by parents of patients with CP, the same procedure was also used for the control group due to the need to create a homogeneous group in relation to the group of respondents.

The QoL of children with CP and healthy children was assessed using the standardised research tool Pediatric Quality of Life Inventory (PedsQL) 4.0 Generic Core developed by James W. Varni. Permission to use the questionnaire was obtained from the Mapi Trust Institute in Lyon.

The graphical interpretation of the data is shown in the form of categorised box plots. The material has been statistically analysed using the Mann-Whitney $U$ test.

The work is part of research already published in the Polish Journal of Paediatrics [10].

The study has been carried out on the basis of the consent (no. KB/469/2014) of the Bioethics Committee of Nicholas Copernicus University in Torun at the Ludwik Rydygier Collegium Medicum in Bydgoszcz.

\section{RESULTS}

A total of 258 respondents participated in the survey based on the PedsQL 4.0. Generic Core questionnaire. Healthy children were characterised by a higher QoL as regards physical and social functioning and functioning in a nursery/kindergarten/school in comparison to the study group. In turn, children with CP had a higher QoL in terms of emotional functioning than their healthy peers. These results are statistically significant $(p<0.05)$. The distribution of results obtained in individual scales is presented in Figure 1.

Analysis of the data obtained indicates that healthy children cope better in all the fields of physical functioning, social functioning, and functioning in the nursery/ kindergarten/school than children with CP. However, as regards emotional functioning, healthy children cope with the feeling of sadness and anger worse $(p<0.05)$. The results as regards the feeling fear are on the limit of significance. Detailed data are presented in Table 1.

The results of three previously analysed scales: emotional functioning, social functioning, and functioning in the nursery/kindergarten/school, make up the results of the psychosocial functioning scale (psycho-social health).

A higher score of psychosocial functioning (Fig. 2) was reported for the group of healthy children, at 80.86 points, while the average score in the group of children with CP was 64.18 points. A higher score for the overall QoL (Fig. 3) was noted in the group of healthy children, at 81.8586 points, while the average score in the group of children with CP was 52.65 points $(p=0.000)$.

\section{DISCUSSION}

The analysis of the results of the authors' own research showed a significant deficit in the QoL of children and adolescents with CP. This complies with the results obtained by other researchers. They confirm that the QoL of persons with CP is lower than that of healthy children $[8,11-17]$. That QoL level can be compared to patients

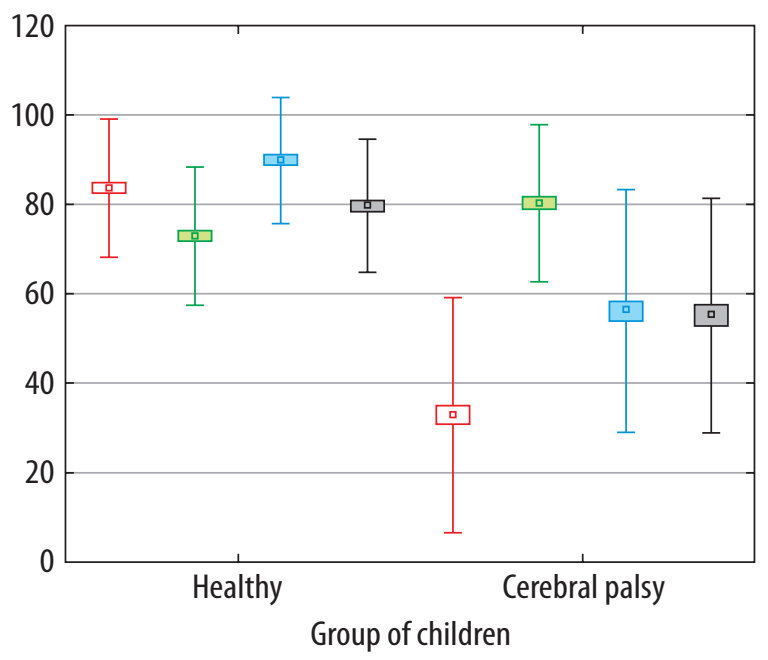

回 Physical functioning

回 Emotional functioning

口 Social functioning

回 Functioning in a nursery/kindergarten/school

FIGURE 1. The distribution of results for the scales of functioning in the studied groups 
TABLE 1. Differences in Pediatric Quality of Life Inventory (PedsQL) 4.0 scale results

\begin{tabular}{|c|c|c|c|c|c|c|c|c|c|}
\hline \multirow[t]{2}{*}{ Variable } & \multicolumn{2}{|c|}{ Sum of ranks } & \multirow[t]{2}{*}{$U$} & \multirow[t]{2}{*}{$Z$} & \multirow[t]{2}{*}{$p$-value } & \multirow[t]{2}{*}{$Z$ correct. } & \multirow[t]{2}{*}{$p$-value } & \multicolumn{2}{|c|}{$n$ import. } \\
\hline & Healthy & $\mathrm{CP}$ & & & & & & Healthy & $\mathrm{CP}$ \\
\hline \multicolumn{10}{|l|}{ Physical functioning } \\
\hline $\begin{array}{l}\text { Hard to walk more than one } \\
\text { block }\end{array}$ & 24149.0 & 9262.0 & 1006.0 & 12.204 & 0.000 & 13.197 & 0.000 & 130 & 128 \\
\hline Hard to run & 24054.5 & 9356.5 & 1100.5 & 12.046 & 0.000 & 12.722 & 0.000 & 130 & 128 \\
\hline Hard to do sport or exercise & 23772.0 & 9639.0 & 1383.0 & 11.575 & 0.000 & 12.083 & 0.000 & 130 & 128 \\
\hline Hard to lift something heavy & 23699.5 & 9711.5 & 1455.5 & 11.454 & 0.000 & 11.870 & 0.000 & 130 & 128 \\
\hline Hard to take bath or shower & 23487.0 & 9924.0 & 1668.0 & 11.099 & 0.000 & 11.716 & 0.000 & 130 & 128 \\
\hline Hard to do house chores & 22074.0 & 11337.0 & 3081.0 & 8.741 & 0.000 & 8.962 & 0.000 & 130 & 128 \\
\hline Hurt or ache & 20482.0 & 12929.0 & 4673.0 & 6.085 & 0.000 & 6.346 & 0.000 & 130 & 128 \\
\hline Low energy & 19962.5 & 13448.5 & 5192.5 & 5.218 & 0.000 & 5.467 & 0.000 & 130 & 128 \\
\hline \multicolumn{10}{|l|}{ Emotional functioning } \\
\hline Feel afraid or scared & 15762.0 & 17391.0 & 7247.0 & -1.691 & 0.091 & -1.799 & 0.072 & 130 & 128 \\
\hline Feel sad or blue & 14617.5 & 18535.5 & 6102.5 & -3.612 & 0.000 & -3.820 & 0.000 & 130 & 128 \\
\hline Feel angry & 13694.0 & 19459.0 & 5179.0 & -5.162 & 0.000 & -5.443 & 0.000 & 130 & 128 \\
\hline Trouble sleeping & 16768.0 & 16385.0 & 8253.0 & -0.003 & 0.998 & -0.003 & 0.998 & 130 & 128 \\
\hline Worry about what will happen & 16412.0 & 16741.0 & 7897.0 & -0.600 & 0.548 & -0.695 & 0.487 & 130 & 128 \\
\hline \multicolumn{10}{|l|}{ Social functioning } \\
\hline Trouble getting along with peers & 18045.5 & 15365.5 & 7109.5 & 2.019 & 0.043 & 2.277 & 0.023 & 130 & 128 \\
\hline Other teens do want to be friends & 20957.5 & 12453.5 & 4197.5 & 6.878 & 0.000 & 7.408 & 0.000 & 130 & 128 \\
\hline Teased at & 21193.0 & 12218.0 & 3962.0 & 7.271 & 0.000 & 7.844 & 0.000 & 130 & 128 \\
\hline Doing things other peers do & 23329.0 & 10082.0 & 1826.0 & 10.835 & 0.000 & 11.454 & 0.000 & 130 & 128 \\
\hline Hard to keep up with peers & 22907.0 & 10504.0 & 2248.0 & 10.131 & 0.000 & 10.724 & 0.000 & 130 & 128 \\
\hline \multicolumn{10}{|c|}{ Functioning in nursery/kindergarten/school } \\
\hline Hard to concentrate & 11774.0 & 6754.0 & 2194.0 & 6.268 & 0.000 & 6.416 & 0.000 & 97 & 95 \\
\hline Forget things & 11815.5 & 6712.5 & 2152.5 & 6.376 & 0.000 & 6.518 & 0.000 & 97 & 95 \\
\hline $\begin{array}{l}\text { Trouble keep up with nursery/ } \\
\text { kindergarten/school work }\end{array}$ & 18606.0 & 7959.0 & 2073.0 & 8.964 & 0.000 & 9.255 & 0.000 & 122 & 108 \\
\hline $\begin{array}{l}\text { Missed nursery/kindergarten/ } \\
\text { school - not well }\end{array}$ & 15319.0 & 11246.0 & 5360.0 & 2.437 & 0.015 & 2.642 & 0.008 & 122 & 108 \\
\hline $\begin{array}{l}\text { Missed nursery/kindergarten/ } \\
\text { school - see doctor }\end{array}$ & 15109.5 & 11455.5 & 5569.5 & 2.021 & 0.043 & 2.173 & 0.030 & 122 & 108 \\
\hline
\end{tabular}

treated for neoplastic and rheumatic diseases $[8,18]$ and patients with meningomyelocele [19].

The results obtained in the authors' own research using the PedsQL 4.0 Generic Core questionnaire for children and adolescents with CP are lower than the results of healthy children, excluding the emotional functioning, which was rated higher $(80.12 \pm 17.519$ vs. $72.81 \pm 15.713)$. The overall QoL was rated lower by the parents of children suffering from CP $(81.85 \pm 11.441$ vs. $52.65 \pm 19.264)$. The physical functioning was rated the lowest by the parents of children with CP, i.e. $32.79 \pm 26.275$ in comparison to the value of $83.61 \pm 15.398$ reported in the group of healthy children. The remaining domains of the scale were rated statistically significantly lower by the parents of children with CP.
The obtained results for the QoL of children in the studied groups may be associated with the education of mothers of children with CP who answered questions in the questionnaire. Analysis of the authors' own research results shows that the highest score as regards emotional functioning was recorded for the group of mothers with primary education, then for those with higher, vocation$\mathrm{al}$, and secondary education (97.50 vs. 83.11 vs. 81.40 vs. 73.06). It should be noted that mothers of children with CP with higher education constituted less than $30 \%$ of the studied group (29.7\%). People with higher education usually have higher knowledge about the child's disease, they better adapt to the therapeutic regime, and consciously participate in the therapeutic process. Von Rueden et al. 

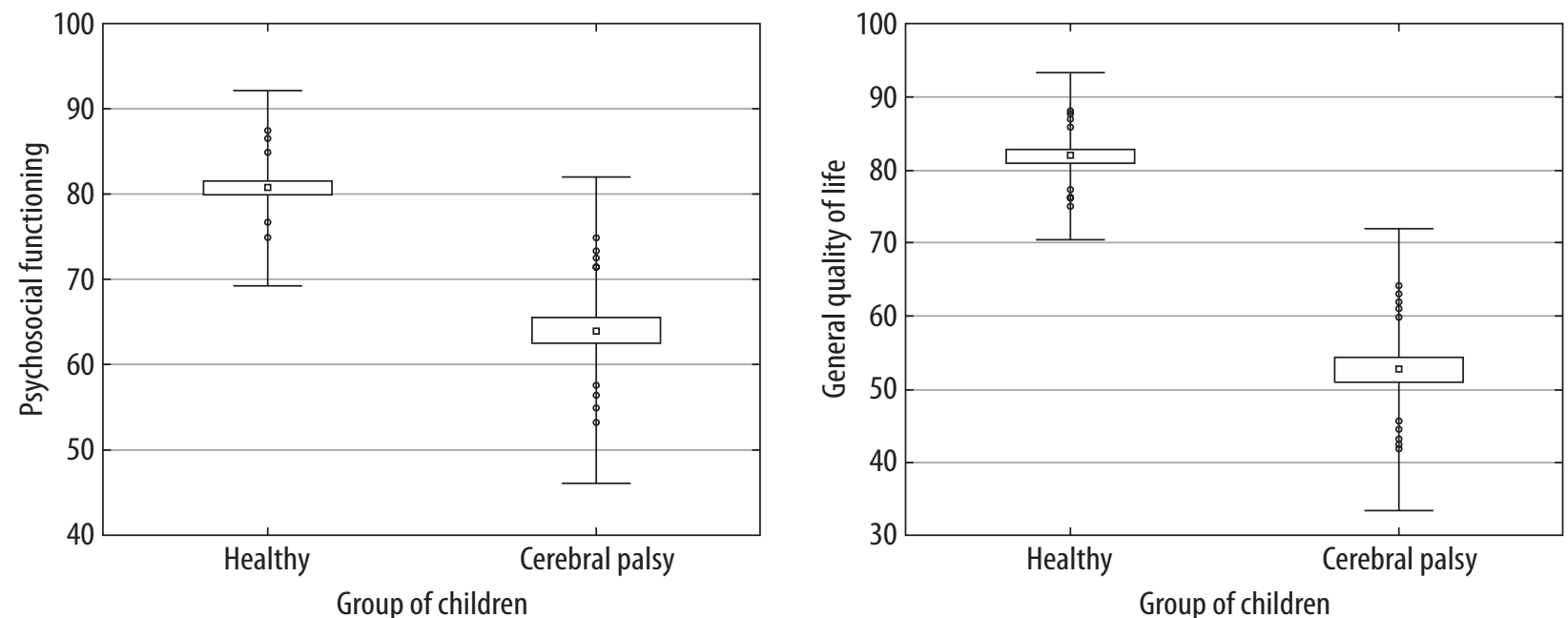

- Average

$\square$ Average \pm standard error

I Average \pm standard deviation

- Outstanding

FIGURE 2. The distribution of average results of psychosocial functioning in the studied groups

reported the relationship between low level of education and low HRQOL scores, with significant differences concerning physical and mental well-being, emotional and school functioning, as well as financial resources [20].

The review of the literature shows that it includes studies in which the authors report a similar QoL of children and adolescents suffering from CP as that of the general population. When examining the QoL using KIDSCREEN, Dickinson et al. found that in the case of $\mathrm{CP}$, the obtained results were similar to the results in the general population; they differed only as regards physical and school functioning [21]. In turn, Majnemer et al. used in her study two generic scales: the Child Health Questionnaire (CHQ) and PedsQL, and found that the QoL of half of the respondents was similar to the QoL of typically developing children [22]. When preparing for the study on the QoL, and then during their implementation, one can encounter difficulties related to the selection of an appropriate assessment strategy. HRQOL can be measured in two ways: objectively, i.e. by third parties, by determining the patient's situation in life; or subjectively, by the patient herself/himself. At present, the significance of the assessment subjectivity is underlined as the patient's own characteristic of the sense of QoL [11, 23-25]. In 1993 the WHO and the International Association for Child and Adolescent Psychiatry and Allied Professions recommended self-reporting as the most appropriate way to measure the QoL in children. In some situations, however, its use may be associated with some limitations, as in the case of the young age of subjects, a serious degree of dysfunction resulting from the disease, and mental disability. In this case, the QoL can be assessed by the parents (proxy-report). Both types of
FIGURE 3. The distribution of mean values of general quality of life in the studied groups

assessment are considered as important, mutually complementary sources of information on the children's QoL, but they are often incompatible with each other $[11,26]$. The differences between the self-report and the assessment performed by other persons are referred to using the term "cross-informant variance" [11, 18, 27]. The professional literature includes inconsistent information on the level of compliance of the QoL assessment between parents and children [11, 27].

When planning our own study on the QoL of patients with CP, it was assumed that the assessment would be performed both by the patients and their parents. Unfortunately, mental disability and communication difficulties in most subjects forced the surveyors to modify the study and limit the analysis to the assessment made only by the carers of patients with CP.

As noted by Owczarek [28], the perception of the disease by patients' surroundings can be very diverse. The family can treat the disease as a task that needs to be dealt with effectively (among others, through changes in the current way of functioning) by deepening knowledge about the disease and active cooperation with physicians. The disease can also be perceived as an embarrassing weakness that should be hidden from the external world by avoiding contact with others. The condition can also be treated as a loss, i.e. it is perceived as incurable, and the patient as someone who can no longer be helped, which manifests itself in the passivity of the people around. The situation is different when the disease is treated as an enemy, i.e. close relatives try, often in a very aggressive way, to fight the disease. Sometimes the disease becomes a strategy of action, which consists of constant demand for help from other people, e.g. from social welfare. For some fam- 
ilies, the occurrence of a chronic disease is a kind of facilitation because it can justify their failures. The disease can also be treated as a punishment for all possible offenses of the family, in the face of which a passive attitude is taken, or as a new experience that should be familiarised with [28]. Wyrwa-Raniszewska claims that the way the disease is perceived by the closest environment affects the patient herself/himself, who notices the attitude of the close family and thus can perceive his/her condition as more or less troublesome, and himself/herself as an obstacle to the normal functioning of the family, which aggravates his/her discomfort associated with the disease experience [29].

\section{CONCLUSIONS}

The QoL of children with CP is lower than that of healthy children. The results achieved in individual domains of the applied questionnaires suggest that there is a need to implement comprehensive therapy for children with CP that enables self-care or assistance in everyday self-care and school activities. It also seems important to adapt the home and school environment in accordance with the needs of patients suffering from CP.

\section{DISCLOSURE}

The authors declare no conflict of interest.

\section{REFERENCES}

1. Zanon MA, Porfírio GJM, Riera R, Martimbianco ALC. Neurodevelopmental treatment approaches for children with cerebral palsy. Cochrane Database Syst Rev 2018; 8: CD011937.

2. Accardo PJ, Capute AJ. Capute and Accardo's neurodevelopmental disabilities in infancy and childhood. Paul H. Brookes Publishing, Baltimore 2008.

3. Reddihough DS, Collins KJ. The epidemiology and causes of cerebral palsy. Aust J Physiother 2003; 49: 7-12.

4. Carlon S, Shields N, Yong K, et al. A systematic review of the psychometric properties of Quality of Life measures for school aged children with cerebral palsy. Pediatrics 2010; 10: 81.

5. Oleś M. Model jakości życia zależnej od zdrowia dla dzieci J. Varniego. In: Jakość życia młodzieży w zdrowiu, Oleś M. KUL, Lublin 2010.

6. Davis E, Shelly A, Waters E, Davern E. Measuring the quality of life of children with cerebral palsy: comparing the conceptual diffrences and psychometric properties of three instruments. Dev Med Child Neurol 2009; 52: 174-180.

7. Waters E, Davis E, Mackinnon A, et al. Psychometric properties of the quality of life questionnaire for children with CP. Dev Med Child Neurol 2007; 49: 49-55.

8. Varni JW, Burwinkle TM, Sherman SA, et al. Chambers HG. Health-related quality of life of children and adolescents with cerebral palsy: hearing the voices of children. Dev Med Child Neurol 2005; 47: 592-597.

9. Gilson K-M, Davis E, Reddihough D, et al. Quality of Life in Children With Cerebral Palsy: Implications for Practice. J Child Neurol 2014; 29: 1134-1140.

10. Lewicka M, Kurylak A. Assessment of quality of life in patients with cerebral palsy. Pediatr Pol 2019; 94: 119-127.
11. Michalska A, Boksa E, Wendorff J, Wiktor PJ. Raport $z$ badań dotyczących problemu jakości życia dzieci i młodzieży z mózgowym porażeniem dziecięcym uczęszczających do placówek Polskiego Stowarzyszenia na Rzecz Osób z Upośledzeniem Umysłowym. https://psoni.org.pl/nasze-publikacje/

12. Dmitruk E. Walidacja i zastosowanie polskiej wersji skali jakości życia dzieci z mózgowym porażeniem dziecięcym the CP QOLChild, rozprawa doktorska 2014.

13. Yang X, Xiao N, Yan J. The PedsQL in pediatric cerebral palsy: reliability and validity of the Chinese version pediatric quality of life inventory 4.0 generic core scales and 3.0 cerebral palsy module. Qual Life Res 2011; 20: 243-252.

14. Garbat M, Paszkowicz MA. Jakość życia osób niepełnosprawnych w województwie lubuskim - diagnoza sytuacji materialno-bytowej In: Jakość życia osób niepełnosprawnych i nieprzystosowanych społecznie, Palak Z (ed.). Wydawnictwo Uniwersytetu Marii Curie-Skłodowskiej, Lublin 2006.

15. Livingston MH, Rosenbaum PL, Russell DJ, et al. Quality of life among adolescents with cerebral palsy: what does the literature tell us? Dev Med Child Neurol 2007; 49: 225-231.

16. Sandella DE, O’Brien LM, Shank LK, et al. Sleep and quality of life in children with cerebral palsy. Sleep Med 2011; 12: 252-256.

17. Bjornson KF, Belza B, Kartin D, et al. Self-reported health status and quality of life in youth with cerebral palsy and typically developing youth. Arch Phys Med Rehabil 2008; 89: 121-127.

18. Varni JW, Limbers CA, Burwinkle TM. Impaired health-related quality of life in children and adolescents with chronic conditions: a comparative analysis of 10 disease clusters and 33 disease categories/severities utilizing the PedsQL 4.0 Generic Core Scales. Health Qual Life Outcomes 2007; 5: 43.

19. Okurowska-Zawada B, Kułak W, Otapowicz D, et.al. Quality of life in children and adolescents with cerebral palsy and myelomeningocele. Ped Neurol 2011; 45: 163-168.

20. von Rueden U, Gosch A, Rajmil L, et al. Socioeconomic determinants of health related quality of life in childhood and adolescence: results from a European study. J Epidemiol Community Health 2006; 60: 130-135.

21. Dickinson HO, Parkinson KN, Ravens-Sieberer U, et al. Selfreported quality of life of 8-12-year-old children with cerebral palsy: A cross-sectional European study. Lancet 2007; 369: 2171-2178.

22. Majnemer A, Shevell M, Rosenbaum P, et al. Determinants of life quality in school age children with cerebral palsy. J Pediatr 2007; 151: 470-475.

23. Zawiślak A. Teoretyczne dylematy dotyczące uwzględniania subiektywnych aspektów jakości życia osób z upośledzeniem umysłowym. In: Pomiędzy teorią a praktyką, Kosakowski C, Krause A, Przybyliński S (eds.). Wydawnictwo Uniwersytetu Warmińsko-Mazurskiego, Olsztyn 2006: 77-82.

24. Trojanowska A. Znaczenie badań nad jakością życia w medycynie. Zdr Publ 2011; 121: 99-103.

25. Użyńska J, Ropiak R, Kowalski IM. Jakość życia młodzieży z chorobą Scheuermanna. Pol Ann Med 2009; 16: 57-69.

26. White-Koning M, Arnaud C, Dickinson HO, et al. Determinants of child-parent agreement in quality-of-life reports: a European study of children with cerebral palsy. Pediatrics 2007; 120: 804-814.

27. Sheffler LC, Hanley C, Bagley A, et al. Comparison of self-reports and parent proxy-reports of function and quality of life of children with below-the-elbow deficiency. J Bone Joint Surg Am 2009; 91: 2852-2859.

28. Owczarek K. Psychospołeczne aspekty padaczki. Epileptologia 1998; 6: 123-127.

29. Wyrwa-Raniszewska A. Doświadczenie somatycznej choroby przewlekłej a poczucie jakości życia. Perspektywa filozoficzno-psychospołeczna. Piel Pol 2013; 1: 37-41. 